\title{
Late Permian paleoclimatic record in the southwest Gondwana Supercontinent: evidence from clay minerals and gamma-ray spectrometry in Paraná Basin, State of Santa Catarina, southern Brazil
}

\author{
Costa, H.S., LPGA-UFPR; Nascimento, M.S., ANBA-UFSC; Ferreira, F.J.F., LPGA-UFPR
}

Copyright 2018, SBGf - Sociedade Brasileira de Geofísica

Este texto foi preparado para a apresentação no VIII Simpósio Brasileiro de Geofísica, Salinópolis, 18 a 20 de setembro de 2018. Seu conteúdo foi revisado pelo Comitê Técnico do VIII SimBGf, mas não necessariamente representa a opinião da SBGf ou de seus associados. É proibida a reprodução total ou parcial deste material para propósitos comerciais sem prévia autorização da SBGf.

\begin{abstract}
The Rio do Sul and Rio Bonito formations in the region of Rancho Queimado in the state of Santa Catarina, southern Brazil, record environmental changes related to climate fluctuations during the drift of the supercontinent Gondwana from the south pole to the Earth's equatorial region. These paleoclimatic variations were have been assessed by clay mineral analysis and gamma-ray spectrometric patterns of outcrops. The data obtained indicate that detrital illite content makes up approximately 50 to $60 \%$ of the clay mineral assemblage. The low $\mathrm{eTh} / \mathrm{K}$ and $\mathrm{eTh} / \mathrm{eU}$ ratios and the detrital illite in the strata of the Rio Bonito Formation indicate a cold and dry climate during deposition. The contrast between the increase in $\mathrm{eTh} / \mathrm{K}$ and $\mathrm{eTh} / \mathrm{eU}$ ratios and the decrease in the illite content toward the top of the Rio Bonito Formation suggests progressively warmer and humid climatic conditions.
\end{abstract}

\section{Introduction}

The sedimentary stratigraphic record suggests that glaciations have occurred episodically throughout the earth's history (Crowell, 1999). One of those glaciations affected the Gondwana Supercontinent during the late Paleozoic and constituted the longest period of continuous glaciation in the Phanerozoic (Eyles, 2003). Carboniferous to Early Permian glaciogenic sedimentary rocks have been identified on all subcontinents of Gondwana, such as, South America (Buatois \& Mangano, 1995; López-Gamundí, 1997; Archanjo et al., 2006), Africa (Scheffler et al., 2003), India (Maejima et al., 2004), Australia (Scheffler et al., 2003), and Antarctica (Collinson et al., 1994; Isbell et al., 2003). This glacial age is subdivided into three episodes (López-Gamundí, 1997): glacial episode I (Late Devonian-Earliest Carboniferous), glacial episode II (Late Carboniferous), and glacial episode III (Late Carboniferous-Early Permian). Sedimentological and stratigraphic studies of PermoCarboniferous sedimentary rocks in the Paraná Basin have suggested a transition of the glacial period to the subsequent global warming that controlled the deep paleoenvironmental change caused by transgressionregression of the Panthalassa at the western edge of the Gondwana Supercontinent (Fig. 1A and 1B). Climate change during late deposition of the Rio do Sul Formation
(Itararé Group) and early deposition of the Rio Bonito Formation (Guatá Group) has been insufficiently studied. Most of the studies on climate records in the Itararé and Guatá Groups (Fig. 1A, 1B and 1C) were based on paleoenvironmental and stratigraphic data (Goldberg, 2001; Holz \& Kalkreuth, 2002; Slonsk, 2002; Cancela, 2008). This work presents gamma-ray spectrometric patterns of $e T h / K$, eTh/U ratios and clay minerals to investigate the paleoclimatic signature during the late sedimentation of the Taciba/Rio do Sul Formation and the early sedimentation of the Rio Bonito Formation in the eastern portion of the Paraná Basin (Fig. 1C). Gammaray spectrometric data reveal important information on paleoclimatic changes (Ruffell and Worden, 2000), and petrographic data may reveal sedimentary provenance in different tectonic environments (Dickinson, 1985).

\section{Methods}

The stratigraphic sections of the Rio do Sul and Rio Bonito Formations were examined and logged at four localities of the Rancho Queimado region (Fig. 1A). The exposures were at road cuttings along the BR-282 (Fig. $1 \mathrm{~A})$. The study outcrops have a wide lateral $(>30 \mathrm{~m})$ and vertical $(5$ to $15 \mathrm{~m}$ ) exposure and include the uppermost portion of the Rio do Sul Formation (BP.09 and BP.67) and the lowermost portion of the Rio Bonito Formation (BP.72 and BP.73) in this region. Four stratigraphic sections on the studied outcrops (BP.67, BP.09, BP.72 and BP.73, Fig. 1) were made. Twelve sandstone thin sections from the Rio do Sul Formation and seven thin sections from the Rio Bonito Formation were analyzed under an optical microscope at the Sedimentary Basin Laboratory (LABAC/UFSC). The diagenetic constituents and clay minerals were studied using a Scanning Electron Microscope (SEM) (JEOL JSM 6010LA) at both the Central Laboratory of Scanning Electron Microscopy (LCME/UFSC), and Laboratory of Minerals and Rocks (LAMIR/UFPR). Four samples of shales were taken from each formation to analyze clay mineral associations using $X$-ray diffraction (XRD) on a PANalytical model $X$ PertPRO-MPD (LAMIR/UFPR) equipped with a vertical goniometer of $240 \mathrm{~mm}$ and a linear detector with a $2,122^{\circ}$ opening (Xcelerator). The spectral radiometric signatures were obtained using the RS-230 handheld gamma-ray spectrometer (Radiation Solutions, Canada) from the Laboratory for Research in Applied Geophysics (LPGA/UFPR). The equipment has a detector with a bismuth germanium oxide (BGO) crystal with 6.3 in $^{3}$ (103 $\mathrm{cm}^{3}$ ) sensitivity. The readings were obtained in counts per minute (cpm) for each element and total count (TC) in parts per million (ppm) for uranium (eU), \% for potassium (K) and ppm for uranium (eU) and thorium (eTh). The 
data were acquired with spacing of $10 \mathrm{~cm}$ (sensor diameter) and an integration time of $120 \mathrm{~s}$. The readings were performed with the instrument positioned perpendicularly to the strata surface. The measured data were stored in the apparatus and transferred to a computer for analysis using RS-Analyst software.

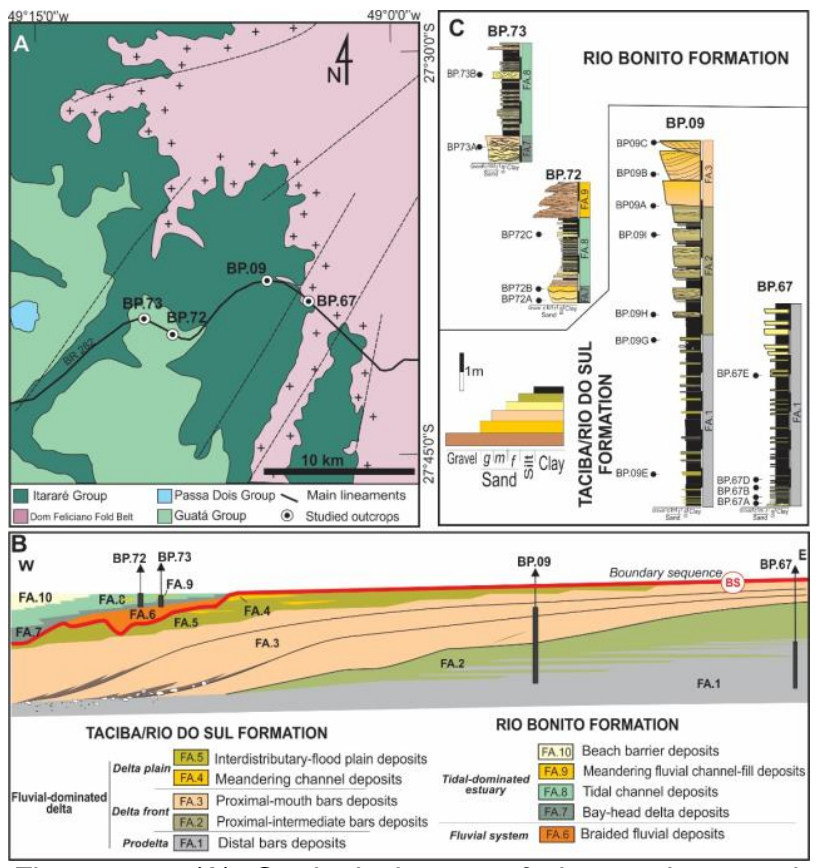

Figure 1 - (A) Geological map of the study area in Rancho Queimado region, with location of outcrops; (B) Schematic stratigraphic section demonstrating the relationship between the main facies and related paleoenvironments; (C) Logged sections of the outcrops with the position of the analyzed samples.

\section{Results}

The clay minerals in the Rio do Sul and Rio Bonito Formations include illite, vermiculite, and interlayered illite-smectite and chlorite (Figs. 2 and 3). The illite was identified by reflections at $10 \AA$ and the vermiculite by reflections at $4.3 \AA$. Octahedral smectite and quartz traces occur. The illite occurs in all samples of the Rio do Sul Member and was not identified in the Rio Bonito Formation (Fig. 3). The illite-smectite interlayers generally occur with associated illite crystals. Illite is the main clay mineral in the Rio do Sul Formation, constituting $50 \%$ to $60 \%$ of the assemblage, and SEM micrographs show dioctahedral-trioctahedral illite (Fig. 2). Vermiculite constitutes $20 \%$ of the clay mineral assemblage in the middle to upper portions of the Rio do Sul Formation. Illite-smectite interlayers represent approximately $1 \%$ of the assemblage. Chlorite was found in only the Rio Bonito Formation (Fig. 3, BP.73).

Gamma-ray spectrometry is a valuable technique to combine with fieldwork to recognize the effect of climatic control on sedimentation. The TC, $\mathrm{K}$, eU and eTh patterns in the Rio do Sul Formation were interpreted in two profiles, as shown in Figure 4.
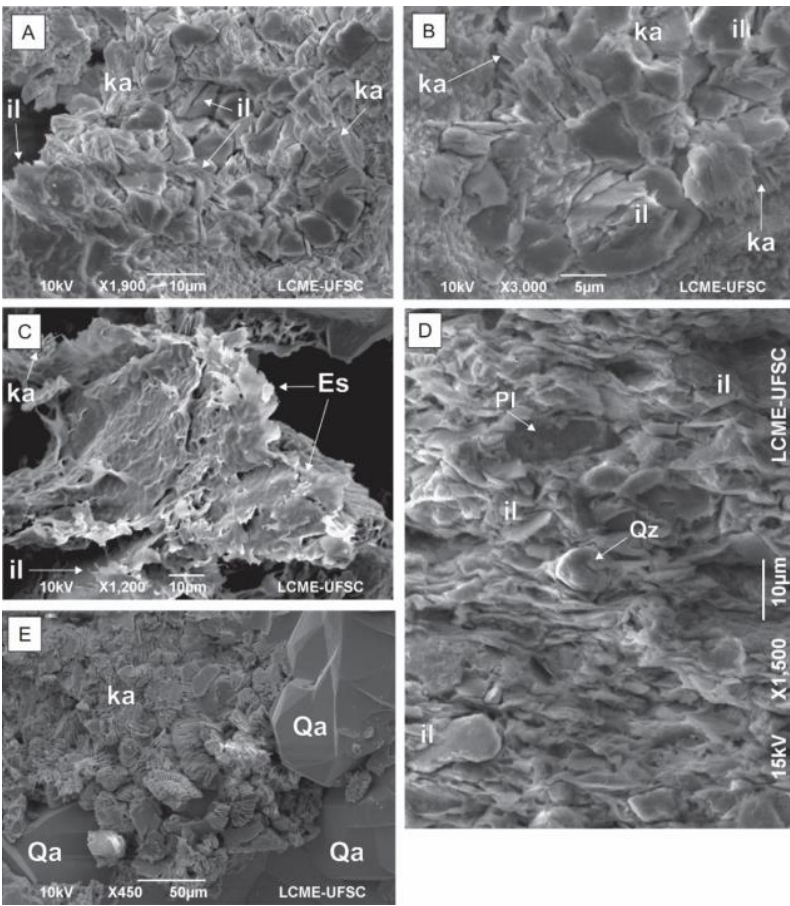

Figure 2 - SEM micrography of the Rio do Sul and Rio Bonito Formations: (A-B) illite (il), quartz grains $(Q z)$ and booklet kaolinite (ka) in sandstones; (C) smectite ( $\mathrm{Sm}$ ) and illite; $(D)$ illite parallel to the lamination, contouring the silty-quartz (Qz) and plagioclase (PI); and (E) booklet kaolinite and authigenic quartz (Qa).
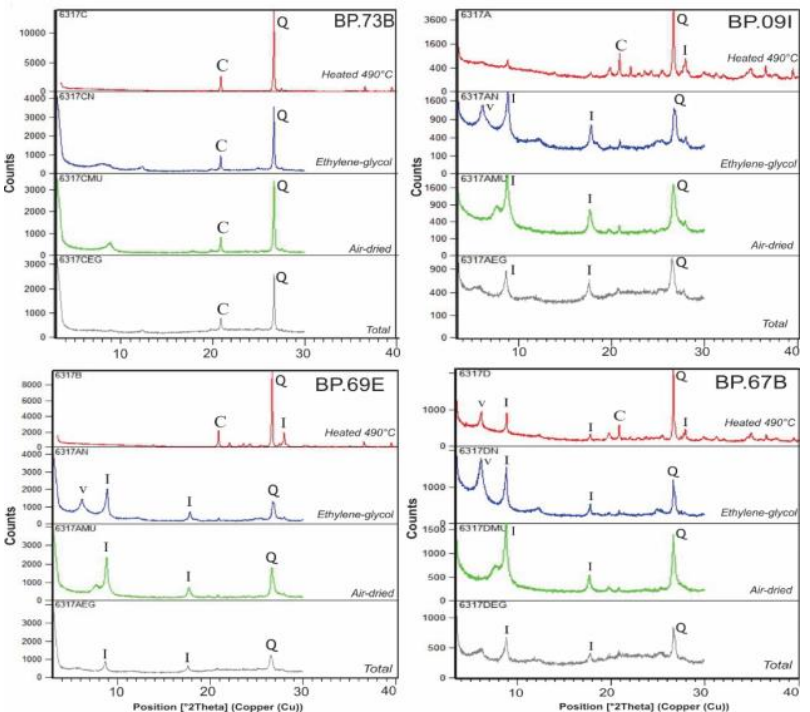

Figure $3-X R D$ traces of main clay minerals (air-dry, ethylene glycol-solvated and heated to $450^{\circ} \mathrm{C}$ ) of the Rio do Sul and Rio Bonito Formations. Illite (I), vermiculite (v), quartz (Q) and chlorite (C). 
Spectral gamma-ray logs of the sandstones have lower $\mathrm{K}$ concentrations (Fig. 4, BP.09 top), ranging from 1.2 to 2.4 $\%$. In contrast, eU presents values approximately 17.9 $\mathrm{ppm}$, having a minimum value of $7.1 \mathrm{ppm}$, and $\mathrm{eTh}$ presents the highest value in this lithofacies (31.0 to 45.9 $\mathrm{ppm})$. The eU and eTh have values of 14 and $40 \mathrm{ppm}$, respectively. In these two lithofacies, TC values show direct correlation with eU and eTh concentrations. The shales show the values range between $2.1 \%$ and $4.9 \%$ (Tab. 1). The eU and eTh show values between 3.6 and $14.3 \mathrm{ppm}$ and between 19.2 and $48.3 \mathrm{ppm}$, respectively. In general, this result indicates that the concentrations of these radionuclides present a gradual increase from the base (Fig. 4, BP.09) to the top (Fig. 4, BP.67) of the session. The TC curves are similar to the curves of $\mathrm{K}$, eU and $\mathrm{eTh}$, showing the relationship with these three elements. The character of the gamma-ray log through the investigated sections shows an upward increase in the concentrations of these radionuclides, illustrating consistency with TC data. However, there is no significant variation in the $\mathrm{eTh} / \mathrm{K}$ and $\mathrm{eTh} / \mathrm{eU}$ ratios since growth is equivalent to the $\mathrm{K}, \mathrm{eU}$ and eTh concentrations. The $\mathrm{eTh} / \mathrm{K}$ and $\mathrm{eTh} / \mathrm{eU}$ ratios from bottom to top of the session show low and relatively homogeneous values $(7$ for $\mathrm{eTh} / \mathrm{K}, 2$ and 8 for $\mathrm{eTh} / \mathrm{eU}$ ). Two gamma-ray profiles were measured in the Rio Bonito Formation (Fig. 5), and data from each lithofacies, including TC, $\mathrm{K}, \mathrm{eU}$ and eTh concentrations, are listed in Table 1. In the sandstones at the base and top portions of this stratigraphic unit (Fig. 5, $\mathrm{BP} .73$ and BP.72), the $\mathrm{K}$ values range from 1.2 to $2.6 \%$, and the eU signatures have values from 2.3 to $28.6 \mathrm{ppm}$. The sandstones at the base of the BP.73 profile (Fig. 5) produce eTh values that gradually increase toward the top of the section. In contrast, the sandstones at the base of the log from BP:72 (Fig. 5), show values ranging from 12 to $17 \mathrm{ppm}$ from the bottom to the top. The TC data are similar to curves of eU and eTh, indicating the influence of these radionuclides on the TC values. The pelites of the Rio Bonito Formation exhibit K contents from 1.8 to $4.2 \%$ (in the lower portion of the BP.73 profile, Fig. 5,) and from 2.6 to $3.2 \%$ (in the upper portion of the BP.72 profile, Fig. 5). The eU measurements are similar to the $\mathrm{K}$ measurements, with $14.7 \mathrm{ppm}$ at the base to $3.0 \mathrm{ppm}$ in the upper portion of the section. At the base of the secession, the eTh values range from 14.2 to $23.5 \mathrm{ppm}$ and strongly correlate with eTh from the upper portion. The TC data have similar patterns to $\mathrm{K}, \mathrm{eU}$ and $\mathrm{eTh}$, indicating the influence of these radionuclide concentrations. The gamma-ray data of the Rio Bonito Formation show a significant upward decrease in the radionuclides concentration, which is more evident in to TC data. The variations in the $\mathrm{eTh} / \mathrm{K}$ and $\mathrm{eTh} / \mathrm{eU}$ ratios are not expressive $(\sim 5)$, but with peaks at $\sim 7$. The increase in $\mathrm{eTh} / \mathrm{K}$ ratios is noted mainly in the sandstones (14 to $25 \mathrm{ppm}$ ), but not accompanied by the eTh/eU ratios, which show a small decrease $(\sim 2)$ in relation to the general pattern $(\sim 2.5$ to 7$)$. The low eTh/eU ratio results from the relative increase in eU concentration in this sedimentary facies.

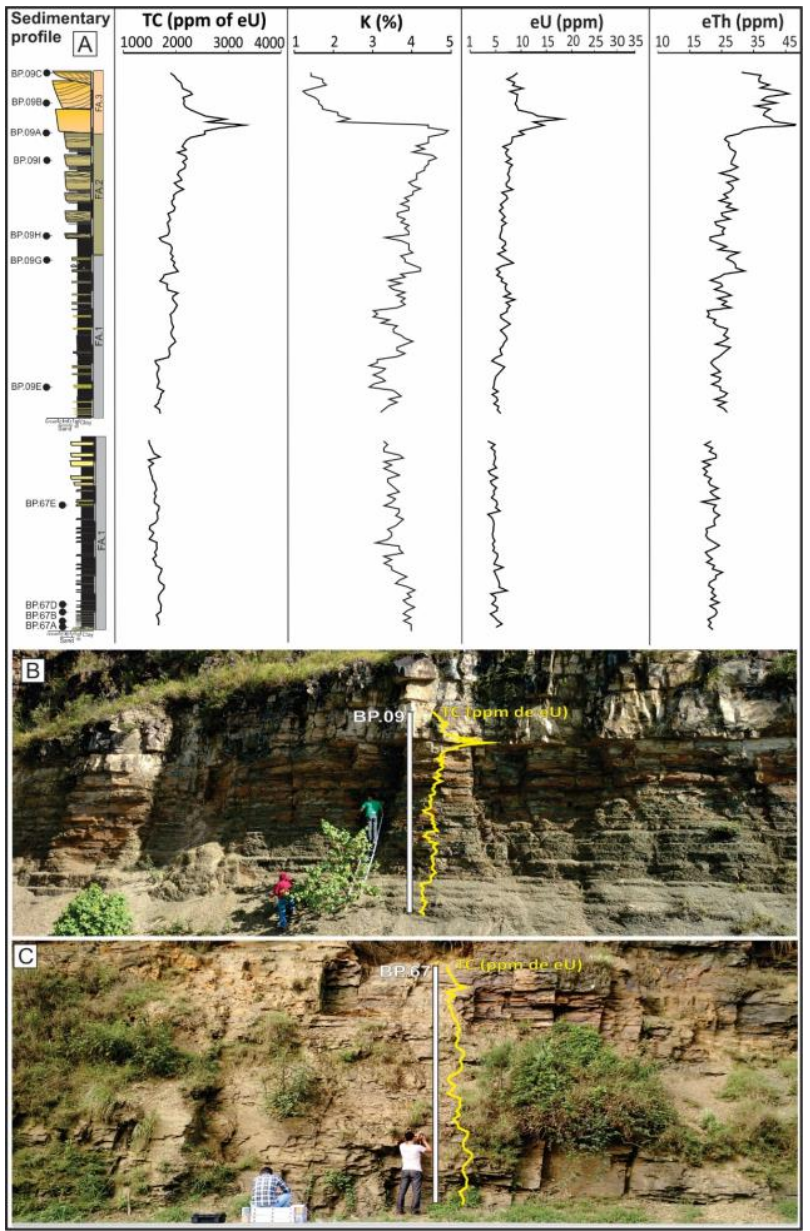

Figure 4 - (A) Sedimentary logs with facies associations, including sample locations and gamma-ray signatures (TC, K, eU and eTh); and (B and C) Field photographs of the outcrops in the Rio do Sul Formation (BP:09 and $B P: 67$, respectively).

\section{Discussion}

The clay mineral assemblage is a significant indicator of paleoclimatic regimes, paleotectonic processes and diagenetic processes. Detrital or authigenic clay minerals are widely used to determine the climatic conditions during sediment deposition (Parry \& Reeves 1968; Singer 1984; Chamley 1989; Tucker 2001; Gonçalves et al., 2006). Illite is the main clay mineral in the Rio do Sul Formation and is ca. 50 to $60 \%$ of the assemblage, especially in the rhythmites and fine-grained sandstones. According to Velde (1995), the illite formation includes slow weathering processes, even in an environment with high- $\mathrm{K}$ availability. The lack of occurrence of smectite in these formations suggests a detrital origin of the illite. The rich $\mathrm{Na}+-\mathrm{K}+$ environments aid in the formation of mixed layers and micas. Vermiculite has a structure similar to smectite, although it is less expandable (Tucker, 2001), indicating leaching of $\mathrm{K}$-feldspar (Kf) during diagenesis or weathering of muscovite under good drainage and low-pH conditions that are very abundant in both fine-grained sandstone and rhythmites. 


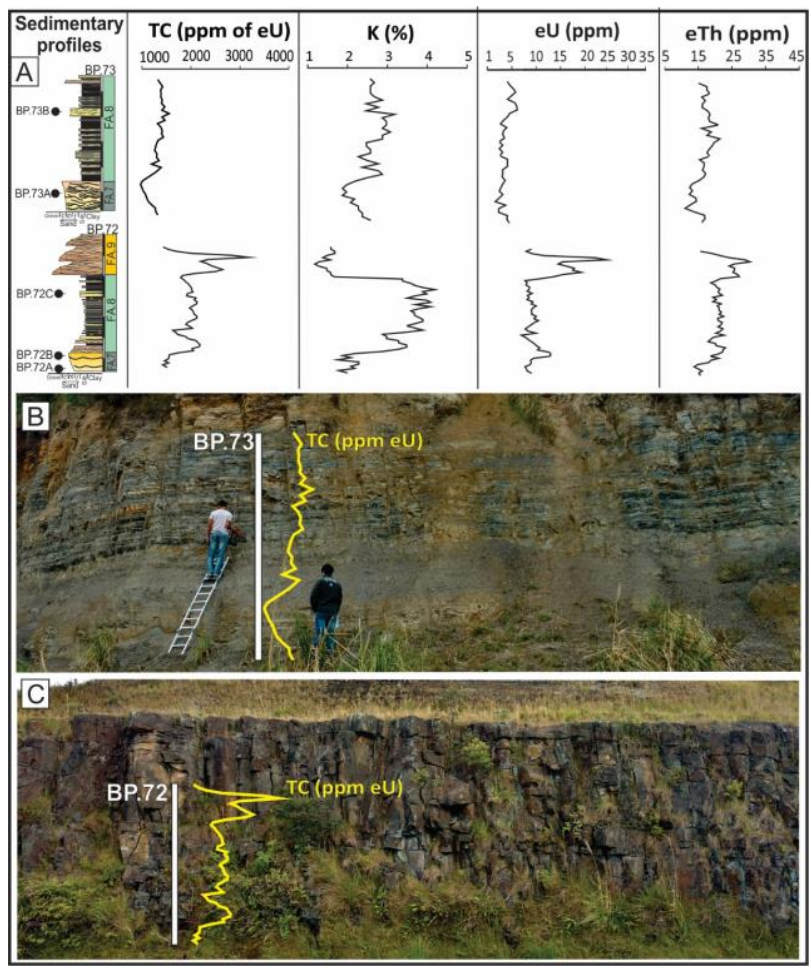

Figure 5 - (A) Sedimentary logs with facies associations, sampled levels and gamma-ray data (TC, K, eU and eTh) of the Rio Bonito Formation; and $(B, C)$ Field photographs of the outcrops (BP:72 and BP:73).

The detrital illite indicates deposition in cold weather, with a tendency toward warmer weather conditions. The depositional context of the Rio do Sul Formation in the studied area involves the movement of the Gondwana Supercontinent from the South Pole to the equatorial region, implying significant climatic and tectonic changes (Milani et al., 2007). In this paleogeographic context, temperatures progressively increased, favoring the formation of clay minerals in increasingly hot and humid climatic conditions, accompanied by transgressive processes (Fig. 6). The gamma-ray spectrometric patterns from shales of the Rio do Sul Formation show low eTh/K (5 to 7) and eTh/eU (2 to 6) ratios from the base to the top of the studied profiles (Fig. 6). However, in the sandstones at the top of the succession, the eTh/K ratios are markedly high ( $>35$ ), indicating the influence of high eU and eTh concentrations (Fig. 6). Although heavy minerals may contain uranium and thorium, the main factor controlling the presence of the radionuclides is their adsorption by organic matter and clays. According to Menezes and Nascimento (2015), the arkose sandstones of the sections studied have rich-feldspar and mica matrix. Therefore, these mineralogical features can influence the $\mathrm{K}$, eU and eTh concentrations in shales. Anomalous values of $\mathrm{K}$, eU and eTh recorded in the sandstones (above) and shales (at the base) interface (see Fig. 6), resulting from the leaching of these radionuclides from the upper strata, which tend to concentrate at the interface of the shales. Shales exhibit high $\mathrm{K}$, eU and eTh because they have low permeability, which limits the intra-stratal dissolution and allows the preservation of these elements (Schnyder et al., 2006). Thus, the eTh/K and eTh/eU ratios from shales can be used as paleoclimatic indicators (Ruffell and Worden, 2000). Although eTh/K and eTh/eU ratios from the base $(<5)$ to the top (>7) of the Rio do Sul Formation indicate a tendency toward arid to cold conditions, it is considered that the progressive increase in these ratios could also indicate a gradual increase in temperature, favoring the remobilization of potassium, uranium, and thorium concentrations. The $\mathrm{eTh} / \mathrm{K}$ and $\mathrm{eTh} / \mathrm{eU}$ ratios in the Rio Bonito Formation (6.0 to 7.3 at the base to ca. 5 at the top) indicate an increase and then decrease in temperature (Ruffell and Worden, 2000). Low eTh/K and eTh/eU ratios indicate cooler weather conditions; thus, the ratios indicate that the temperatures became progressively hotter and wetter, alternated by cycles of aridization of the environment.

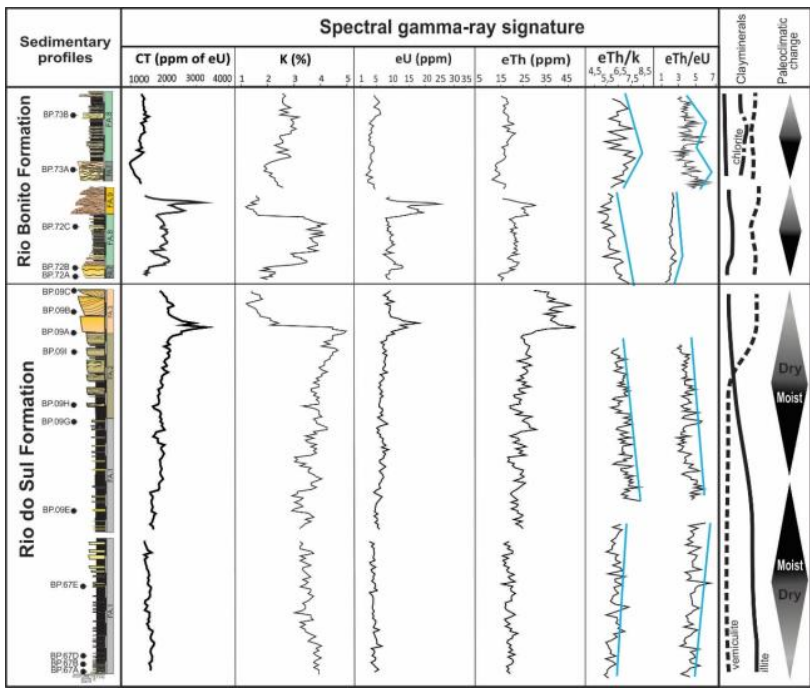

Figure 6 - Paleoclimatic interpretation of the Rio do Sul Member and Rio Bonito Formation from gamma-ray spectrometry and clay minerals mineralogy.

\section{Conclusions}

Clay mineralogy through the Rio do Sul and Rio Bonito formations indicates alternating moist and arid phases. The abrupt climate change toward a more arid environment is supported by the dataset of the present paper. This aridity coincides with a cold interval, suggesting a relationship between cold and arid conditions during the late Permian. The eTh/K and eTh/U ratios suggest an arid and cold climate during deposition of the base of the Taciba Formation, as indicated by detrital illite. The progressive increase in the eTh/K and $\mathrm{eTh} / \mathrm{U}$ ratios toward the top indicates greater $\mathrm{K}$ and $\mathrm{eU}$ leaching with respect to eTh, suggesting more humid and hot climates. The $\mathrm{eTh} / \mathrm{K}$ and $\mathrm{eTh} / \mathrm{U}$ ratios of the Rio Bonito Formation indicate a temperature increase toward the top of this formation. However, the oscillations in these ratios suggest momentary enrichment in $\mathrm{K}$ and $\mathrm{eU}$ with respect to $\mathrm{eTh}$, which is also indicated by the variations in the $\mathrm{e} T \mathrm{~h} / \mathrm{K}$ and $\mathrm{e} T \mathrm{~h} / \mathrm{U}$ ratios. 


\section{Acknowledgments}

The authors thank to Petrobras for supporting this research under the contract PFRH240-PB-UFSC. We are very grateful to Almério Barros França, Leonardo Fadel Cury and Valter Antonio Becegato for their suggestions and assistance in the LAMIR/UFPR laboratory, and to Itaipu Binacional by the lending of the gamma-ray spectrometer. F.J.F. Ferreira thanks the support of the National Council for Scientific and Technological Development (CNPq) for this study, under contract 306978/2015-6.

\section{References}

Buatois, L.A., Mangano, M.G., 1995. The paleoenvironmental and paleoecological signifi cance of the lacustrine Mermia ichnofacies: An archetypical subaqueous nonmarine trace fossil assemblage. Ichnos $4,151-161$.

Cacela, A.S.M., 2008. Paleoclima e dinâmica costeira como fatores controladores da distribuição de arenitos em sistemas paralíticos - Um estudo para reservatórios análogos no Eopermiano da Bacia do Paraná. Dissertação de Mestrado, Instituto de Geociências, Universidade Federal do Rio Grande do Sul, Brasil.

Chamley, H., 1989. Clay Sedimentology. Spriger-Verlag, Berlin, 623.

Crowell, J. C., 1999. Pre-Mesozoic ice ages: Their bearing on understanding the climate system. Geological Society of America Memoir 192.

Dickinson, W.R., 1985. Interpreting provenance relations from detrital modes of sandstones. In: Zuffa, G.G. (Eds.), Provenance of Arenites. Reidel Publ., Dordrecht, 333 361.

Eyles, C.H., Mory, A.J., Eyles, N., 2003. CarboniferousPermian facies and tectono-stratigraphic successions of the glacially infl uenced and rifted Carnarvon Basin, western Australia. Sedimentary Geology 155, 63-86.

Gonçalves, D.F.; Rossetti, D.F.; Truckenbrodt, W.; Mendes, A. C., 2006. Argilominerais da Formação Codó (Aptiano Superior), Bacia de Grajaú, Nordeste do Brasil. Latin American Journal of Sedimentology and Basin Analysis 13, 59-75.

Goldberg, K., 2001. The Paleoclimatic Evolution of the Permian of the Paraná Basin in southern Brazil. Ph.D. Dissertation, Department of Geophysical Sciences, University of Chicago, $267 \mathrm{pp}$.

Holz, M., Kalkreuth, W., 2002. Sequence Stratigraphy and Coal Petrology applied to the Early Permian coal-bearing Rio Bonito Formation, Paraná Basin, Brazil. American Association of Petroleum Geology, Special Publication, 45-56.

López-Gamundí, O.R., 1997. Glacial-postglacial transition in the late Paleozoic basins of southern South America, in
Martini, I.P., (Eds.), Late Glacial and Postglacial Environmental Changes. Oxford, UK, Oxford University Press, 147-168.

Maejima, W., Das, R., Pandya, K.L., Hayashi, M., 2004. Deglacial control on sedimentation and basin evolution of Permo-Carboniferous Talchir Formation, Talchir Gondwana Basin, Orissa, India. Gondwana Research 7, 339-352.

Menezes, M.T.F., Nascimento, M.S., 2015. Petrografia e diagênese de arenitos permianos da Bacia do Paraná, região de Alfredo Wagner, Santa Catarina IX SIMPÓSIO SULBRASILEIRO DE GEOLOGIA. Florianópolis, Santa Catarina. Sociedade Brasileira de Geologia Núcleo RS/SC. Boletim de resumos, p.15.

Milani E.J., Melo J.H.G., Souza P.A., Fernandes L.A., França A.B., 2007. Bacia do Paraná. In: Milani E.J., Rangel H.D., Bueno G.V., Stica J.M., Winter W.R., Caixeta J.M., Pessoa Neto O.C., (Eds.), Bacias Sedimentares Brasileiras - Cartas Estratigráficas. Boletim de Geociências da Petrobras, Rio de Janeiro, 15(2): 265287.

Parry, W.T., C.C., Reeves, 1968. Clay mineralogy of pluvial lake sediments, Southern High Plain, Texas. Journal of Sedimentary Petrology 38, 516-529.

Ruffell, A., Worden, R., 2000. Palaeoclimate analysis using spectral gamma-ray data from the Aptian (Cretaceous) of southern England and southern France. Palaeogeogr. Palaeocl., 155(3-4), 265-283.

Scheffler, K., Hoernes, S., Schwark, L., 2003. Global changes during Carboniferous-Permian glaciation of Gondwana: Linking polar and equatorial climate evolution by geochemical proxies. Geology, 31(7), 605-608.

Schnyder, J., Ruffell, A., Deconinck, J.F., Baudin, F., 2006. Cojuntive use of spectral gamma - ray logs and clay minerals in drilling Late Jurassicearly Cretaceous paleoclimate change (Dorset, U.K.), Paleo. Paleo. Paleo. 229, 303-320.

Singer, A., 1984. The paleoclimatic interpretation of clay minerals in sediments-a review. Earth Science Reviews 21, 251-293.

Slonski, G.T., 2002. Interpretação paleoclimática do Permiano Inferior da Bacia do Paraná em Santa Catarina, Brasil (Formação Rio Bonito). Dissertação de Mestrado, Centro de Ciências Biológicas, Universidade Federal de Santa Catarina, Brasil.

Tucker, M.E., 2001. Sedimentary Petrology: an introduction to the origin of sedimentary rocks. 3nd edition, Oxford, Blackwell, 262 pp.

Velde, B., 1995. Origin and mineralogy of clay minerals. Springer, Berlin. 334p. 
Table 1. Gamma-ray spectrometric data from sandstones and shales of the Rio do Sul and Rio Bonito Formation.

\begin{tabular}{|c|c|c|c|c|c|c|c|c|}
\hline \multirow{2}{*}{$\begin{array}{c}\begin{array}{l}\text { Rio do Sul } \\
\text { Formation }\end{array} \\
\text { Elements }\end{array}$} & \multicolumn{4}{|c|}{ Sandstones (16 samples) } & \multicolumn{4}{|c|}{ Shales (153 samples) } \\
\hline & $\begin{array}{c}\mathrm{TC} \\
(\mathrm{ppm} / \mathrm{eU})\end{array}$ & $\begin{array}{c}K \\
(\%)\end{array}$ & $\begin{array}{c}\mathrm{eU} \\
(\mathrm{ppm})\end{array}$ & $\begin{array}{l}\text { eTh } \\
\text { (ppm) }\end{array}$ & $\begin{array}{c}\mathrm{TC} \\
(\mathrm{ppm} / \mathrm{eU})\end{array}$ & $\begin{array}{l}\mathrm{K} \\
(\%)\end{array}$ & $\begin{array}{c}\mathrm{eU} \\
(\mathrm{ppm})\end{array}$ & $\begin{array}{l}\text { eTh } \\
\text { (ppm) }\end{array}$ \\
\hline Mean & 2240.82 & 1.60 & 9.77 & 38.65 & 1855.87 & 3.70 & 6.02 & 24.80 \\
\hline $\begin{array}{l}\text { Standard } \\
\text { deviation }\end{array}$ & 248.82 & 0.30 & 2.62 & 3.32 & 249.53 & 0.40 & 1.55 & 3.75 \\
\hline $\begin{array}{l}\text { Variation } \\
\text { coefficient }\end{array}$ & 0.11 & 1.18 & 0.26 & 0.08 & 0.13 & 0.10 & 0.25 & 0.15 \\
\hline Maximum & 2945.20 & 2.40 & 17.90 & 45.90 & 3302.20 & 4.90 & 14.30 & 48.30 \\
\hline Minimum & 1919.70 & 1.20 & 7.10 & 31.30 & 1532.50 & 2.10 & 3.60 & 19.20 \\
\hline $\begin{array}{l}\text { Rio Bonito } \\
\text { Formation }\end{array}$ & \multicolumn{4}{|c|}{ Sandstones (38 samples) } & \multicolumn{4}{|c|}{ Shales (63 samples) } \\
\hline Elements & $\begin{array}{c}\mathrm{TC} \\
\text { (ppm/eU) }\end{array}$ & $\begin{array}{c}\mathrm{K} \\
(\%)\end{array}$ & $\begin{array}{c}\mathrm{eU} \\
(\mathrm{ppm})\end{array}$ & $\begin{array}{c}\mathrm{eTh} \\
\text { (ppm) }\end{array}$ & $\begin{array}{c}\mathrm{TC} \\
(\mathrm{ppm} / \mathrm{eU})\end{array}$ & $\begin{array}{c}K \\
(\%)\end{array}$ & $\begin{array}{c}\mathrm{eU} \\
(\mathrm{ppm})\end{array}$ & $\begin{array}{l}\text { eTh } \\
\text { (ppm) }\end{array}$ \\
\hline Mean & 1693.01 & 1.84 & 10.70 & 19.90 & 1677.07 & 3.06 & 7.70 & 19.50 \\
\hline $\begin{array}{l}\text { Standard } \\
\text { deviation }\end{array}$ & 681.60 & 0.40 & 8.00 & 6.00 & 336.29 & 0.63 & 3.10 & 2.30 \\
\hline $\begin{array}{l}\text { Variation } \\
\text { coefficient }\end{array}$ & 0.40 & 0.21 & 0.74 & 0.30 & 0.20 & 0.20 & 0.40 & 0.11 \\
\hline Maximum & 3166.00 & 2.60 & 28.60 & 30.90 & 2177.30 & 4.20 & 14.70 & 23.50 \\
\hline Minimum & 923.30 & 1.20 & 2.30 & 11.50 & 1140.00 & 1.80 & 3.00 & 14.20 \\
\hline
\end{tabular}

